\title{
The Present Role of Liver Biopsy in Kidney Transplant Candidates in the Management of Hepatitis B and C Patients
}

\author{
Teresa Casanovas, Carme Baliellas and Maria Carmen Peña Cala \\ Hospital Universitari de Bellvitge, Institut Català de la Salut, \\ IDIBELLL, Hospitalet de Llobregat-Barcelona, \\ Spain
}

\section{Introduction}

This chapter will deal with the present role of Liver Biopsy in determining liver disease prognosis in hepatitis B and C patients on haemodialysis and its role in establishing treatment strategies and in the decision-making process prior to kidney transplant. In recent years, progress has been made in determining the natural history of this disease in renal patients (Espinosa et al., 2004; Jadoul et al., 2004).

Chronic hepatitis due to $\mathrm{HCV}$ is frequent in renal transplant recipients and in dialysis patients and has a significant impact on their survival (Hanafusa et al., 1998; Orloff et al., 1995; Pouteil-Noble et al., 1995). Mathurin et al., (1999) demonstrated in a case-control study that anti-HCV and HBsAg positive were independently associated with patient and graft survival. This was the first time that a 10 year follow-up was carried out; previous publications are based on shorter follow-ups and fewer patients.

It is known that the prevalence of chronic infection with the hepatitis $C$ virus (HCV) in patients with chronic kidney disease is higher than in the general population (Lavanchy, 2009). The estimated prevalence of chronic infection in haemodialysis patients is $13 \%$, ranging from 10 to $65 \%$, depending on the geographical zone (Hmaied et al., 2006; Huraib et al., 1995; Santos \& Souto, 2007; Shamshiraz et al., 2004).

When considering patients candidates to kidney transplantation we have to take into account that immunosuppressive therapy after renal transplantation predisposes a reactivation of chronic viral hepatitis $B$ or $C$, which is usually a mild disease for patients remaining under haemodialysis.

It should be noted that HBV and HCV may induce de novo glomerulonephritis and chronic allograft nephropathy which can lead to graft failure (Aouifi \& Garcia, 2001). In such cases, patients have to undergo dialysis again and therefore it is beneficial to eradicate HCV RNA before transplantation and to control and maintain HBV DNA negative (Huskey \& Wiseman, 2011).

A routine liver histological analysis could improve a patient's chance of being selected for renal transplantation. Liver biopsy has been considered the "gold standard" for many years, because it provides us with information that was otherwise unobtainable (Ghany et al., 2010). Nowadays however, due to progress in non-invasive methods, liver biopsy is only 
necessary in selected cases or in patients with a lack of correlation between clinical and analytical data (Alric et al., 2009; Stasi et al., 2009).

In solid organ transplant patients, who are $\mathrm{HBV}$ or $\mathrm{HCV}$ carriers under immunosuppressives, an increasing frequency of fibrosing cholestatic hepatitis has been described. This type of hepatitis evolves rapidly to liver cirrhosis, significantly increases morbidity and mortality and leads to the need for a liver transplantation in selected cases (Boletis et al., 2000; Delladetsima et al., 1999; Vallet-Pichard et al., 2011). (Table 1).

\begin{tabular}{|c|c|}
\hline Typical viral hepatitis & Fibrosing cholestatic hepatitis \\
\hline $\begin{array}{l}\text { - Portal lymphocytic infiltrates are } \\
\text { observed, with various degrees of } \\
\text { periportal interface inflammatory } \\
\text { activity. } \\
\text { Lobular necroinflammatory change is } \\
\text { present, the inflammatory component } \\
\text { chiefly lymphocytic. Granulomatous } \\
\text { hepatitis, have been reported in chronic } \\
\text { HCV infection. } \\
\text { Different morphologic changes are } \\
\text { specifically seen in particular } \\
\text { hepatotropic virus: } \\
\text { a. HCV: Portal lymphoid aggregates } \\
\text { and follicles, focal duct damage, } \\
\text { and mild fatty change often occur. } \\
\text { b. HBV: “Ground glass" cells and } \\
\text { sometimes mild fatty change may } \\
\text { be seen. }\end{array}$ & $\begin{array}{l}\text { Described in patients under } \\
\text { immunosuppressors and related to a } \\
\text { direct viral cytopathic effect on the liver } \\
\text { cells and although fibrosing cholestatic } \\
\text { hepatitis is seen in both HBV and HCV } \\
\text { infection, it is more common in the } \\
\text { former. } \\
\text { Portal expansion with periportal and } \\
\text { intrasinusoidal collagen deposition, bile } \\
\text { ductular proliferation, but with minimal } \\
\text { portal inflammation are seen. } \\
\text { Prominent ballooning change of liver } \\
\text { cells occurs, with associated cholestasis } \\
\text { but mild lobular inflammation. } \\
\text { Variable but sometimes prominent fatty } \\
\text { change (steatoviral) may occur. In } \\
\text { severe cases, bridging and multiacinar } \\
\text { necrosis can be seen, leading to the graft } \\
\text { failure. }\end{array}$ \\
\hline
\end{tabular}

Table 1. Chronic Hepatitis major morphologic features. Typical viral hepatitis vs Fibrosing cholestatic hepatitis. (Adapt., Kanel, G. C. \& Korula, J. (2011) Atlas of Liver Pathology, Elsevier Saunders, ISBN: 978-1-4377-0765-6)

\section{General approach}

\subsection{Preliminary considerations}

Active $\mathrm{HCV}$ infection in dialysis patients, namely HCV-RNA positive by PCR, requires evaluation of liver fibrosis preferentially by liver biopsy. New tools for assessing fibrosis by non-invasive methods have been developed, and although they have yet to be validated for chronic kidney patients they will be discussed in this chapter.

General management of chronic viral hepatitis and in particular the indication of liver biopsy, in a practical clinical approach, has the objective to avoid liver-related mortality and to promote allograft survival in kidney transplanted patients (Sezer et al., 2004).

\subsection{Historical background}

Over the past few decades, medical progress has been made and new specialities have emerged in areas such as solid organ transplants and chronic viral hepatitis treatments. Nephrology and hepatology specialities have to plan an interdisciplinary care approach for 
patients candidates for transplantation and for those receiving immunosuppressors especially in hepatitis virus carriers (Fabrizi et al., 2010a, Carriero et al., 2008).

One quarter of $\mathrm{HCV}$ positive patients evaluated for a kidney transplant have advanced fibrosis or cirrhosis in the liver biopsy. In the past they should require a combined liver and kidney transplant. Currently, this concept is not fully accepted, for the following two reasons:

1. Due to the scarcity of donors some patients with cirrhosis or advanced liver fibrosis, but never decompensated, are being accepted for renal transplantation only .

2. Liver biopsies, which were mandatory several years ago, are being replaced by noninvasive methods in mild or severe hepatitis. However, patients diagnosed inconclusively must undergo a liver biopsy to confirm the diagnosis (Sebastiani \& Alberti, 2006).

\subsection{Our experience}

In 1991 we initiated a prospective, non-randomized study to assess the tolerability and efficacy of Interferon (IFN) alfa for treating chronic hepatitis C in kidney transplant candidates undergoing haemodialysis. The aims were to evaluate the efficacy and safety of IFN alfa in this setting. We studied HCV RNA status at the end of treatment and during follow-up and the complications related to haemodialysis, to primary renal disease, and to the use of IFN during treatment. We also studied the evolution of the kidney graft in transplanted patients and the evolution of hepatitis after transplantation to investigate the risk of accelerated liver disease. It should be noted that although we now evaluate the results of the anti-virals with viral kinetics, at the begining of the study PCR qualitative of RNA-HCV was the only available method.

This study was published in 2001, and the results showed that $64 \%$ had Sustained Viral Response (SVR) and HCV-RNA was repeatedly negative during the follow-up (CasanovasTaltavull et al., 2001). Moreover a lesser development of de novo glomerulonephritis was observed in patients to whom IFN alfa had been administered (Cruzado et al., 2003).

We have to take into account that in those days our dialyzed patients had a higher prevalence of viral hepatitis. The prevalence of HBV and HCV infections has markedly decreased in patients who are candidates for transplantation since the introduction of screening, hygiene and prevention measures, including systematic vaccination against HBV, screening of blood and organ donations, use of erythropoietin, compliance with universal hygiene rules, and isolation of HBV-infected and $\mathrm{HCV}$ positive patients from non-infected patients (Fabrizi et al., 2004).

Blood transfusions were common in the past because they were thought to improve graft tolerance and erithropoietin had yet to be approved for this indication (Light et al., 1982).

While an anti-Hepatitis B vaccine is indicated in these patients, an anti-HCV vaccine has yet to be developped. Preventive and general measures are therefore crucial for stopping viral transmission (Sauné et al., 2010).

\section{Clinical spectrum and natural history of the disease}

\subsection{Epidemiology and prevalence of liver diseases in patients under substitutive renal treatment}

Reports on the natural history of hepatitis $C$ infection in the dialysis population vary and consequently is not completely understood. The slow progression of the HCV-associated liver disease may mask the consequences of $\mathrm{HCV}$ infection in the dialysis population (Okoh 
et al., 2008). Previous studies that focused on liver disease demonstrated a low proportion of $\mathrm{HCV}$-positive dialysis patients with bridging hepatic fibrosis or cirrhosis (Gane \& Pilmore, 2002).

The possible explanation for such a distinct difference is a reduction of the viral load via adsorption of viral particles with their subsequent destruction (Kaiser et al., 2008). In the same way, alanine aminotransferase (ALT) may be filtered through the dialyser membrane and ALT levels may be normal in patients with otherwise advanced liver disease (Lopes et al., 2006).

Because of the persisting contradictions reported, there is an urgent need for better communication between specialists to establish clear guidelines for the management of chronic viral hepatitis in ESRD patients. Phase 3 trials of new antivirals, in combination with pegIFN and ribavirin in the general population, which have a primary end point of SVR efficacy, are expected to be performed. Before administering these new drugs to patients under hemodialysis it will be necessary to perform PK studies and to obtain a toxicological profile of these new drugs in this setting.

\title{
3.2 Risk factors (Table 2) some concerns
}

Studies on viral isolates have suggested a nosocomial patient-to-patient transmission of $\mathrm{HCV}$ infection among dialysis patients in some centers despite dialysis centers having routine protocols to prevent hepatitis transmission and to control the infection (McLaughlin et al., 1997). Several dilemmas regarding the management of these patients have yet to be resolved:

1. Should HCV-RNA testing and complete HBV serologies be included in the routine screening of HD population for chronic hepatitis infection, considering the fact that anti-HCV remains positive even in cured patients and that in some RNA-HCV positive cases, antibodies may be negative ("occult-hepatitis") (Angelico et al., 2000).

2. Does periodic serum ALT testing have a role in HD patients for hepatitis infection although it is known that ALT may be normal in this population?

3. Should HCV or HBV-infected subjects be isolated and dialyzed by segregated machines? This situation is not totally resolved and can lead to misunderstandings among medical teams and cured patients.

\author{
Intravenous drug use \\ Number of blood transfusions received before 1999 \\ Duration of hemodialysis \\ Mode of dialysis \\ Prevalence of $\mathrm{HCV}$ infection in the dialysis unit \\ Previous organ transplantation \\ Male gender / Older age \\ Intravenous drug use \\ Previous HBV infection \\ General risk of nosocomial transmission of $\mathrm{HCV}$
}

Table 2. Risk Factors for HCV infection in dialysis patients (Alavian, S. M., 2009).

\subsection{Impact of transplantation on the natural history of hepatitis}

Renal Transplantation is recognized as the treatment of choice in most patients with end stage renal disease but the decision-making process for kidney transplant in hepatitis cases 
is complex. Recently, however, it has been shown that clinical evolution is better in patients who have received a kidney transpant, even in those who are non responders to antivirals, than in patients who have to remain under haemodialysis. (Sezer et al., 2004).

\subsection{Hepatitis $B$ virus (HBV) in renal patients}

Although the prevalence of hepatitis B virus (HBV) infection has declined in haemodialysis patients and in renal transplant recipients, it remains high within countries with endemic HBV infection (especially Asia-Pacific and Africa). Renal transplantation is associated with reduced survival in HBsAg+ hemodialysis patients (Aroldi et al., 2005).

Treatment of hepatitis B is indicated among kidney transplanted patients and haemodialysis patients with HBV in replicative phase, (same indications as the general population) but the anti-HBV treatment has to be pursued as a preventive measure once the patient has received the transplant in order to avoid progression of the liver disease which could affect the liver and also the graft (Daudé et al., 2011).

Lamivudine used to be the only option for such cases but severe forms of exacerbation were described due to resistant mutants. Present anti-HBV therapy based on nucleos(t)ide analogues, such as tenofovir or entecavir, are now recommended. They are more potent, have a higher genetic barrier than lamivudine and are well tolerated. The dosing and administration depends on the creatinine clearance (Vigano et al., 2005).

Treatment with entecavir or tenofovir is indicated in all HBsAg-positive candidates for transplantation and after transplantation in order to maintain HBV DNA negative. Better graft survival has been described in HBsAg negative patients in comparison with patients with $\mathrm{HBV}$ infection (HBsAg positive or only anti-HBc positive) undergoing immunosuppressor treatment (Gane \& Pilmore, 2002).

A liver biopsy in HBV positive patients has to be considered when image test results, such as ultrasound echography or fibroscan, are unclear or misleading and if there is no correlation between clinical and analytical data. A three phase liver CAT (Computed Axial Tomography) scan with injection of contrast medium is indicated when an ultrasound echography detects signs of a possible tumour.

Whatever the baseline histological evaluation, with the new anti-HBV anti-virals, sustained suppression of necro-inflammation may result in regression of fibrosis or cirrhosis, which in turn may lead to decreased disease-related morbidity and improved survival (ValletPichard et al., 2011). Regular monitoring with liver function tests and HBV DNA measurements should enable early detection and rescue in case of appearance of demonstrated virus resistance.

\subsection{Hepatitis $\mathrm{C}$ virus (HCV) in renal patients}

We consider that haemodialysis patients (presenting no severe co-morbidities or contraindications) are candidates to anti-HCV treatment only if they are being evaluated for the waiting list for kidney transplant and as long as they have no contraindications to interferon therapy, because the evolution of hepatitis $C$ is generally mild for patients remaining on dialysis (Kidney Disease Improving Global Outcomes [KDIGO], 2008).

Although anti-HCV treatment must be proposed to all candidates for renal transplantation who had no contraindications to interferon, whatever their baseline histopathology, in $\mathrm{HCV}$-infected patients undergoing chronic dialysis who are non-candidates for renal transplantation, the indication for antiviral therapy has to be individualized and is usually limited to patients with significant fibrosis (Gordon et al., 2009). 
After transplantation, interferon- $\alpha$ is contraindicated but may be used in patients for whom the benefits of antiviral treatment clearly outweigh the risks, especially that of allograft rejection. Due to this risk, dialysis patients recieving anti-viral treatment are taken off the waiting list.

Questions about efficacy and safety of $\mathrm{HCV}$ treatment have yet to be resolved because practice and guidelines accepted for the general population cannot be applied to dialysed cases. These patients are considered as a special population and the treatment is only indicated for selected cases after weighing the pros and cons. Sustained viral response rates as high as 50 to $60 \%$ have been demonstrated with interferon monotherapy in dialysis (Fabrizi et al., 2008; Fabrizi et al., 2010a).

The therapeutical anti-viral option with pegylated interferon was incorporated in 2000 to the protocols for HCV treatment and adopted for the management of dialyzed patients due to its positive results and because it requires only one injection a week. Previously, standard interferon was administered three times weekly after every dialysis session. Currently, the question of whether results with pegylated interferon are better than those observed in the past with standard interferon remains unanswered. Ribavirine was totally contraindicated in uremic patients, but due with a better sustained response to anti-HCV treatment obtained with the combination of pegilated interferon and ribavirine in the general population, it now has a role in the HCV treatment in patients undergoing dialysis (Fabrizi et al., 2010b).

Concerns about its use are present due to the risk of severe anemia in this setting. Combining ribavirine in uremic cases has only been accepted with extreme caution regarding doses, recommending only $200 \mathrm{mg}$, 1 pill a week. In the event of good tolerance the dose may be increased to 2-3 pills weekly, always combined with erythropoietin (Carriero et al., 2008).

Treatment of chronic HCV infection with pegylated interferon and ribavirin in kidney transplant recipients is associated with a risk of acute or chronic cellular rejection of $30 \%$ or more, resulting in graft loss and reduced patient survival. Therefore, indications for treatment must be tailored accordingly. The indication should be assessed on a case-by-case basis, if $\mathrm{HCV}$ infection is life-threatening.

Hepatitis $\mathrm{C}$ virus (HCV) infection influences glomerular pathologic findings in renal allografts and affects the graft outcome. In diagnostic renal allograft biopsies, after kidney transplant, the presence of de novo immune-mediated glomerulonephritis has been observed, especially type I membrano prolipherative glomerulonephritis (MPGN), which is strongly associated with $\mathrm{HCV}$ infection and results in accelerated loss of the graft. Cruzado et al., (2003) proved that patients previously treated with interferon were less at risk of developing MPGN.

\section{Diagnostic procedures}

\subsection{Serological assays and blood liver tests}

The assessment of liver disease should include biochemical markers, such as alanine aminotransferase (ALT) and aspartate aminotransferase (AST), gamma-glutamyl transpeptidase (GGT), alkaline phosphatase, bilirubin, prothrombin time or INR (International Normalized Ratio); albumin; gammaglobulins and full blood counts. Abdominal ultrasound should be obtained as basic hepato-biliary imaging (Kidney Disease Improving Global Outcomes [KDIGO], 2008).

Various serological assays are available for the diagnosis and follow-up of HCV infection. Third generation serological tests for determining the presence of $\mathrm{HCV}$ antibodies are 
highly sensitive and specific. In case of positive serology, viral load should be determined by HCV RNA. In addition, quantitative real time PCR should be determined at least once in each patient in order to diagnose cases that have 'escaped' lower-sensitivity tests (Angelico et al., 2000).

ALT, as mentioned previously, is a helpful, although non-specific, marker of the presence of $\mathrm{HCV}$ infection in the dialysis population. Serial determinations of ALT are vague when reflecting the severity of liver disease and do not correlate with the liver histology or viral load (Lopes et al., 2006).

According to our experience, all patients with end-stage renal disease should undergo serological tests to screen for HCV and HBV and have their status confirmed by PCR before starting renal replacement therapy (hemo-dialysis, peritoneal dialysis).

\subsection{Non-invasive imaging techniques}

The ideal non-invasive test has to be simple and reproducible, readily available, easy to perform, less expensive than biopsy, and able to predict the full spectrum of fibrosis and to reflect changes occurring over time (Gaiani et al., 1997; Lackner et al., 2005).

The majority of studies have focused on HCV cases, the most prevalent liver disease in the general population, but there are few studies addressing chronic kidney patients under dialysis treatment (Alric et al., 2009).

Non-invasive methods include blood/serum markers and imaging/scanning techniques. Ultrasonography and Elastography (Fibroscan) combined with blood indexes, are the most reliable for detecting liver cirrhosis. However, in kidney patients their clinical use is limited because they have not been totally validated. This is a developing field and in the future a combination of data will probably be available in order to establish prognosis and diagnosis of cirrhosis.

\subsubsection{Blood tests to diagnose chronic liver disease}

Fibrosis assessment in research is done with serum fibrosis markers which can be divided into direct and indirect markers, with a preference for indirect markers.

a) Direct markers are involved in the formation of an extracellular matrix during fibrosis, and indirect markers reflect hepatic dysfunction. Several studies on the diagnosis of liver cirrhosis using direct fibrosis markers, such as collagen and hyaluronic acid, had a low sensitivity and specificity (approximately 80\%). Fibrosis markers are expensive and not available for clinical practice.

b) Indirect fibrosis markers include the AST-to-ALT ratio (AAR), the AST-to-platelet ratio index (APRI), and Forns's index (Forns et al., 2002) which is the most popular as it enables the required data to be obtained easily.

Sebastian et al. (2009) have published results showing that combining the results of fibroscan and blood tests may reduce the indication of liver biopsy. In clinical practice diagnosis of compensated cirrhosis is based on ultrasonography and routine blood tests.

\subsubsection{Ultrasonographic (US) imaging}

Ultrasonographic (US) imaging with Doppler analysis is being widely used for the diagnosis of chronic hepatitis and compensated and decompensated cirrhosis.

US is safe, inexpensive, and routinely used within hospitals, it is also available in individual doctor's practices and in mobile settings. It offers real-time capability without the need for much data processing and analysis. However, it is recognized that the US technique needs a skilled operator, which is an important drawback. 
The combination of gray scale US and Doppler US improves diagnostic accuracy and is essential for diagnosis of cirrhosis or fibrosis. It is known that liver fibrosis and steatosis can have similar appearances and can be present at the same time in a "fatty-fibrotic pattern" (Borrioni et al., 2006). US can show a small, nodular liver in advanced cirrhosis, but surface nodularity or increased echogenicity can be seen in hepatic steatosis as well as in cirrhosis (Hirche et al., 2007).

\begin{tabular}{|c|c|c|}
\hline & ADVANTAGES & DISADVANTAGES \\
\hline Liver biopsy & $\begin{array}{l}\text { - Great experience } \\
\text { - Evaluates other parameters in } \\
\text { addition to fibrosis } \\
\text { - Accurately differenciates } \\
\text { varying stages of fibrosis }\end{array}$ & $\begin{array}{l}\text { - Sampling errors } \\
\text { - Varies depending on the } \\
\text { observer's interpretation } \\
\text { - Invasive method (morbidity } \\
\text { and mortality) } \\
\text { - Hospitalization required } \\
\text { - Expensive }\end{array}$ \\
\hline $\begin{array}{l}\text { Hepatic Elastography } \\
\text { (Fibroscan) }\end{array}$ & $\begin{array}{l}\text { - Good reproductibility } \\
\text { - More comprehensive } \\
\text { assessment of liver tissue } \\
\text { - Non-invasive method } \\
\text { - Does not require admission } \\
\text { - Inexpensive }\end{array}$ & $\begin{array}{l}\text { - No experience in dialysis } \\
\text { patients } \\
\text { - Less applicable if obesity, } \\
\text { ascites, or/and small intercostal } \\
\text { spaces } \\
\text { - Unreliable fibrosis results if } \\
\text { cholestasis, cytolysis or liver } \\
\text { edema } \\
\text { - Only evaluates fibrosis } \\
\text { - Does not discriminate between } \\
\text { intermediate stages of fibrosis }\end{array}$ \\
\hline
\end{tabular}

Table 3. Theoretical advantages and disadvantages of liver biopsy and hepatic transient elastography of the liver in patients on dialysis, providing the lack of validation studies.

Gaiani et al., (1997) investigated the accuracy of an ultrasonographic score derived from liver, spleen, and portal vein features in predicting the final diagnosis in patients with compensated chronic liver disease. After comparing results obtained by ultrasonography to those obtained by percutaneous liver biopsy, they identified liver surface nodularity and portal flow velocity as factors independently associated with cirrhosis. Enlargement of the caudate lobe and spleen size besides the specific echogenicity pattern have been found to be associated with cirrhosis in other studies. Spleen size was assessed longitudinally and considered normal up to $12 \mathrm{~cm}$.

A model consisting of liver surface nodularity obtained by echography, may be useful for the identification of compensated cirrhosis with a high degree of accuracy in daily practice, when a platelet count of less than $100,000 / \mathrm{mm}^{3}$, an albumin level of less than $3.5 \mathrm{~g} / \mathrm{dL}$, and a prothrombin time or an INR of more than 1.3, is observed.

Albumin and prothrombin time or INR indicate the synthetic activity of the liver and platelet count reflects the degree of portal hypertension. As these variables, excepting the platelet count, are used in the Child-Pugh scoring system, the most used classification for cirrhosis prognosis, the specificity of the items appears to be high.

The albumin level and INR has more than 95\% specificity in identifying cirrhosis, but sensitivity is low. A platelet count of less than $100,000 / \mathrm{mm}^{3}$ has been widely accepted as the cut-off level of portal hypertension. 
With strengths and limitations, the usual blood tests and ultrasonographic variables are the basis for the diagnosis of compensated liver cirrhosis (Fontana \& Lok., 2002; Sebastiani et al., 2006).

\subsubsection{Hepatic elastography (fibroscan)}

The fibrogenic evolution of chronic viral hepatitis B and C towards cirrhosis represents a key issue in clinical hepatology. Traditionally, liver fibrosis has been assessed by liver biopsy. One of the most important reasons for which a liver biopsy has been indicated in many situations including patients with chronic renal failure and viral hepatitis is fibrosis assessment. The liver biopsy has a low although non-negligible morbidity and mortality rate.

The fragment of liver tissue studied is small and represents only $1 / 50.000$ of the liver. Liver biopsy obtains a semiquantitative result leading to a possible inaccurate fibrosis assessment, because fibrosis is heterogeneously distributed. Furthermore, the evaluation of the specimen requires an experimented pathologist to give his/her diagnostic opinion. There may therefore be cases of inter or intra-observer variations. Some studies show that there can be differences of up to $35 \%$ variability and of up to $20 \%$ interobservational, which can lead to errors when studying the hepatic fibrosis of a particular patient (Standish et al., 2006).

In the past ten years, non-invasive methodologies have been proposed to predict the presence of fibrosis in chronic liver disease, especially the introduction of transient elastography or FibroScan ${ }^{\circledR}$ (Castera et al., 2005; Ziol et al., 2005) which represents a further advancement.

This technique is based on the estimate of liver tissue elasticity by ultrasound. This is done by measuring the speed of propagation of a mechanical wave within the liver parenchyma. Results, expressed in kilo Pascals, are obtained from the speed of the recorded wave (meters / second). Hepatic elastography provides a number of advantages compared to liver biopsy (Table 3).

The evaluated tissue volume is about 100 times bigger than the biopsy which is therefore likely to be much more representative of the total liver tissue. As it is non-invasive, this method can be repeated in the same patient. It has also shown good reproducibility between observers. Nevertheless, this technique also has its limitations. In 5-15\% of patients it is impossible to use because of its inability to pass the mechanical wave and to reach the liver in obese patients and in patients with small intercostal spaces or due to the presence of ascites. Furthermore, some situations or comorbidities of the patient may produce unreliable results of this test. This can occur if there is liver stasis, marked elevation of transaminases or a presence of significant cholestasis. Hepatic elastography has demonstrated a high sensitivity and specificity enabling a correct diagnosis of fibrosis even when cirrhosis is already present, but this method is not as efficient for classifying intermediate fibrosis stages. Establishing the exact stage of fibrosis can be improved by using hepatic elastography in conjunction with fibrosis serum markers or the fibrotests mentioned above. Fibroscan has proved its utility in diverse liver diseases (chronic HCV or HBV, NASH, sclerosing cholangitis....) in immunocompetent patients but also in immunosuppressed patients such as in recurrent chronic hepatitis C after liver transplantation. There are no specific studies comparing liver biopsy to transient elastography for assessing liver fibrosis in patients with chronic renal failure on dialysis. Probably, and by analogy with other populations, this could be useful. We must bear in mind that it is more important 
to establish the fibrosis stage and disregard cirrhosis in such patients, which consequently entails a different management of the patient, even though anti-viral treatment is always indicated, in order to protect the renal graft after transplantation. In addition, liver biopsy in patients on dialysis has a higher morbidity and higher risk of bleeding in comparison to the general population. Specific studies well designed to assess the usefulness of elastography versus liver biopsy in patients undergoing dialysis would be justified.

\subsubsection{Combination of blood test and fibroscan}

Fibroscan can only evaluate tissue elasticity, however when it is combined with blood tests and new algorithms it can be indicated in different liver diseases. In the future, new formulas combining Fibroscan and diagnostic characteristics will be available for more reliable prognosis in different etiologies. A summary of current methods for assessing fibrosis are exposed in Table 4.

\begin{tabular}{|c|c|c|c|c|}
\hline \multicolumn{5}{|c|}{ CURRENT METHODS FOR ASSESSING FIBROSIS } \\
\hline INVASIVE & $\begin{array}{l}\text { LIVER } \\
\text { BIOPSY }\end{array}$ & \multicolumn{3}{|c|}{$\begin{array}{l}\text { Needs specific preparation and nowadays is only } \\
\text { indicated in selected patients }\end{array}$} \\
\hline \multirow[t]{5}{*}{$\begin{array}{l}\text { NON- } \\
\text { INVASIVE }\end{array}$} & & & $\begin{array}{l}\text { Blood/Serum } \\
\text { markers }\end{array}$ & $\begin{array}{l}\text { Settings in which } \\
\text { validation exists }\end{array}$ \\
\hline & & APRI & AST to platelets ratio & Hepatitis B and C \\
\hline & & Fib-4 & $\begin{array}{l}\text { Age,AST,ALT, } \\
\text { platelets }\end{array}$ & Hepatitis C \\
\hline & & Fibro-Test, & $\begin{array}{l}\text { Alpha2- } \\
\text { macroglobulin, GGT, } \\
\text { haptoglobin, } \\
\text { apolipoprotein A1, } \\
\text { total bilirubin }\end{array}$ & $\begin{array}{l}\text { Hepatitis B and } \\
\text { C, alcoholic } \\
\text { hepatitis, non- } \\
\text { alcoholic fatty } \\
\text { liver }\end{array}$ \\
\hline & & Forns' Index & $\begin{array}{l}\text { Combination of } \\
\text { GGT, cholesterol, } \\
\text { BMI age }\end{array}$ & Hepatitis B and C \\
\hline \multicolumn{5}{|c|}{ IMAGING/SCANNING TECHNIQUES } \\
\hline \multicolumn{2}{|c|}{$\begin{array}{l}\text { Ultrasonography with Doppler } \\
\text { analysis }\end{array}$} & \multicolumn{3}{|c|}{$\begin{array}{l}\text { Identification of portal hypertension. Doppler measures } \\
\text { velocity of blood flow and hemodynamic variations }\end{array}$} \\
\hline \multicolumn{2}{|c|}{ Elastography (Fibroscan), } & \multicolumn{3}{|c|}{$\begin{array}{l}\text { Liver stiffness. Not possible if: presence of ascites, } \\
\text { narrow intercostal spaces, obesity }\end{array}$} \\
\hline \multicolumn{2}{|c|}{ Computed Tomography } & \multicolumn{3}{|c|}{$\begin{array}{l}\text { Identifies microvascular changes, but can not be } \\
\text { performed in renal failure or in patients who are contrast } \\
\text { allergic }\end{array}$} \\
\hline \multicolumn{2}{|c|}{ Magnetic Resonance } & \multicolumn{3}{|c|}{$\begin{array}{l}\text { Observes changes in liver parenchyma. Useful studying } \\
\text { tumours. High cost }\end{array}$} \\
\hline
\end{tabular}

Table 4. Current methods for assessing fibrosis

\subsection{Liver biopsy}

At present, cases with an inconclusive diagnosis can only be resolved by liver biopsy. Liver biopsy is considered the "gold standard" for obtaining information concerning the extent of 
$\mathrm{HCV}$-associated liver disease and further non-suspected diagnosis such as hemosiderosis, steatosis, non-alcoholic fatty liver disease etc. Liver biopsy should be carried out in the initial study of all patients except in cases of contraindications or clinical and/or ultrasonographic established cirrhosis. Desmet et al. (2003a)

Liver biopsy is an invasive procedure which is associated with an increased risk of bleeding in dialysis patients. A liver biopsy may be obtained percutaneously or via the transjugular route which is associated with a lower risk. In addition, the transjugular approach can be used to measure the hepatic venous pressure gradient and confirm the existence of portal hypertension.

Nowadays, liver biopsy only seems to be mandatory in the evaluation of non-conclusive cases. In such cases an assessment of the severity of the liver disease is needed for choosing the most suitable treatment. There is an urgent need for non-invasive validated markers of hepatic fibrosis in this setting.

\subsubsection{Liver biopsy procedure}

Before the liver biopsy procedure, imaging studies and a detailed coagulation analysis have to be performed to investigate hepatobiliary disease. Because of the high risk of bleeding in uremic patients, in our unit, liver biopsy is obtained after a dialysis session without heparin. An hematocrit at least, of $30 \%$ is mandatory; patients whose hematocrit levels are below this value receive a blood transfusion. To improve platelet function, a dose of $0.3 \mathrm{mg} / \mathrm{kg}$ of body weight of Minurin (Ferring SA, Madrid, Spain) is administered intravenously 30 minutes before the biopsy when indicated by hemostatic studies. Transjugular liver biopsy is used in patients with platelet levels of less than $100,000 / \mathrm{mm} 3$, and a percutaneous approach using a needle which is guided by Computed Tomography or Ultrasonography, and not blindly as in the past, is indicated in patients with normal coagulation analysis and in those in whom it is not necessary to measure portal pression. A better specimen is obtained using this last approach.

\subsubsection{Histological assessment}

The primary objective of histologic assessment is to evaluate disease progression in all forms of compensated liver disease independently of etiology (viral, toxic, metabolic etc.) and to evaluate the extent and type of hepatic fibrosis. Biopsies have to be evaluated by experienced pathologists.

Thus staging of liver fibrosis represents the most useful data for prognosis. Specimens are processed with routine stains, hematoxylin and eosin, and connective tissue stains (reticulin and trichrome method staining) used for accurate assessment of liver architecture and hepatic fibrosis. Specimens are stained by the periodic acid-Schiff method, and the presence of hemosiderin in macrophages and Kupffer cells is investigated by Perl's iron stain method. The presence of hepatitis B surface and core antigen is searched for in the cytoplasm and nucleus respectively, by immunohistochemistry. If a positive staining for either antigen is found, it is indicative of a replicative phase of HBV chronic infection.

Fat accumulation in hepatocytes ("steatosis") appears as clearly defined transparent spaces within the cytoplasm and can be both macro and microvesicular in nature. Moreover many of the liver diseases that contain fat have associated inflammation (e.g. neutrophils in alcoholic hepatitis, lymphocytes in chronic viral hepatitis due to HCV infection).

Pathologists have developed scores for reading and interpreting liver biopsies by sharing and correlationing their results with clinical data. Histologic staging (degree of fibrosis) and grading (degree of necroinflammatory activity) has become a very useful tool for the 
clinician when deciding the prognosis and therapeutic options. It is recommended to begin the histologic description with the etiology of hepatitis (e. g., chronic hepatitis C) followed by the degree of fibrosis, and the degree of activity, with appropriate numerical codes using one classification and scoring system. Various scoring systems have been validated for use in chronic hepatitis C. Desmet et al. (2003b)

The most widely used in Europe are METAVIR, Scheuer, Ishak, and Knodell's Hepatitis Activity Index. Metavir and Scheuer's scores are more reproducible and less prone to observer variation, but less discriminant both for fibrosis and for necroinflammation than Ishak and Knodell (Table 5).

\begin{tabular}{|c|c|c|c|}
\hline FIBROSIS STAGE & DESCRIPTION & CRITERIA & \\
\hline 0 & No fibrosis & Normal connective tissue & \\
\hline 1 & Portal fibrosis & Fibrous portal expansion & \\
\hline 2 & Periportal fibrosis & $\begin{array}{l}\text { Periportal or rare portal- } \\
\text { portal septa }\end{array}$ & \\
\hline 3 & Septal fibrosis & $\begin{array}{l}\text { Fibrous septa with } \\
\text { architectural distortion; } \\
\text { no obvious cirrhosis }\end{array}$ & \\
\hline 4 & Cirrhosis & Cirrhosis & \\
\hline $\begin{array}{l}\text { INFLAMMATORY } \\
\text { GRADE }\end{array}$ & DESCRIPTION & $\begin{array}{l}\text { LYMPHOCYTIC } \\
\text { PIECEMEAL NECROSIS }\end{array}$ & $\begin{array}{l}\text { LOBULAR } \\
\text { INFLAMMATION } \\
\text { AND NECROSIS } \\
\end{array}$ \\
\hline 0 & $\begin{array}{l}\text { Portal } \\
\text { inflammation } \\
\text { only; no activity }\end{array}$ & None & None \\
\hline 1 & Minimal & Minimal, patchy & $\begin{array}{l}\text { Minimal, occasional } \\
\text { spotty necrosis }\end{array}$ \\
\hline 2 & Mild & $\begin{array}{l}\text { Mild, involving some or } \\
\text { all portal tracts }\end{array}$ & $\begin{array}{l}\text { Mild, little } \\
\text { hepatocellular change }\end{array}$ \\
\hline 3 & Moderate & $\begin{array}{l}\text { Moderate, involving all } \\
\text { portal tracts }\end{array}$ & $\begin{array}{l}\text { Moderate, } \\
\text { with noticeable } \\
\text { hepatocellular change }\end{array}$ \\
\hline 4 & Severe & $\begin{array}{l}\text { Severe, may have } \\
\text { bridging fibrosis }\end{array}$ & $\begin{array}{l}\text { Severe, with } \\
\text { prominent diffuse } \\
\text { hepatocellular damage }\end{array}$ \\
\hline
\end{tabular}

Table 5. The liver biopsy interpretation in chronic hepatitis: Staging and Grading Systems (Batts, 1995, as cited in Kanel, G. C. \& Korula, J. (2011) Atlas of Liver Pathology)

In our unit, biopsies are scored according to the classical system proposed by Scheuer, in which necroinflammatory activity (portal/periportal hepatitis and lobular activity) and fibrosis are evaluated separately, and are classified on a scale of a $0-4$, as follows: F0, no fibrosis; F1, portal fibrosis; F2, periportal fibrosis; F3, septal fibrosis; and F4, cirrhosis based on the recommended criteria. Bile duct and cholangiolar proliferation may be present but are not prominent, except in instances of severe liver cell injury. Other findings such as iron deposits are studied in Kupffer and liver cells and are classified as mild, moderate, or severe. But over the years, steatosis, non-alcoholic fatty liver, has become more important. 
Liver biopsy provides information regarding the presence or absence of cirrhosis especially if a study of portal pression is incorporated to the procedure. In the cirrhotic stage, the regenerative nodules are often "macronodular", more than $3 \mathrm{~mm}$. If they are less than $3 \mathrm{~mm}$, they are micronodular. Sometimes a mixed pattern with both macro and micronodules can be detected.

Recently, the great advances in radiological imaging techniques have focused attention on hepatic premalignant nodular lesions. The histological differential diagnosis of these nodules can often be difficult, especially in needle biopsy specimens with limited material. Diagnostic considerations differ significantly between livers with and without cirrhosis: In the noncirrhotic liver, the differential diagnosis includes liver cell adenoma, nodular regenerative hyperplasia, and hepatocellular carcinoma. In cirrhosis, dysplastic nodules (low and high grade), dysplasia (large and small cell) as well as hepatocellular carcinoma may occur. The standardization and the uniform use of the nomenclature of these entities are necessary for a better understanding of the biological nature and etiopathology of these lesions. Only a commonly accepted nomenclature makes a comparison of different therapeutic treatment regimens feasible.

Liver biopsy also assesses the disease severity by evaluating the parenchyma structure and other possible tissue damage related to non-suspected lesions. It helps to determine the degree of disease progression, the need for anti-viral treatment, patient motivation and the indication of a combined liver and kidney transplant.

\subsubsection{Diagnosis of hepatic fibrosis and cirrhosis}

Cirrhosis can be defined as the end stage consequence of fibrosis of the hepatic parenchyma resulting in nodule formation and altered hepatic function.

Up to $40 \%$ of patients with cirrhosis are asymptomatic and may remain so for more than a decade, but progressive deterioration is inevitable once complications develop, including ascites, variceal hemorrhage or encephalopathy. Early diagnosis of liver cirrhosis in chronic hepatitis patients is critical in its management. All cirrhotic patients, notably after solid organ transplantation, should be screened for hepatocellular carcinoma. Liver biopsy increases costs and has potential risks, however, diagnosis of compensated liver cirrhosis usually requires doing a liver biopsy and assessment of portal hypertension (fibrosgastroscopy and direct measurement). Liver biopsy is the most accurate diagnostic method in the diagnosis of compensated liver cirrhosis, but a liver biopsy is performed in few patients in clinical practice.

Complications in the general population are very low $(1 / 4000-10,000)$, but the risk of hemorrhage in uremics has to be taken into account, false negative probability due to sampling error is reported to be of 20 to $30 \%$. A liver specimen obtained to be evaluated has to be more than $1 \mathrm{~cm}$ in length.

For these reasons, nowadays it is necessary to establish non-invasive diagnostic methods, validated predominantly for chronic $\mathrm{HCV}$, to allow for an easier diagnosis of liver cirrhosis in different populations.

\subsubsection{Liver biopsy data in dialysis patients}

A few researchers have evaluated histologic severity of liver disease in HCV-positive patients with end stage renal disease. Martin et al., (2000) reported 37 anti-HCV positive patients, who were referred for renal transplant, most of whom were already dialysis dependent and had undergone liver biopsy. Mild or moderate necroinflammatory activity 
occurred in all patients; bridging fibrosis was present in 3 of $37(8 \%)$, and frank cirrhosis in 9 (24\%). No relationship between severity of histologic changes and HCV viral load or genotype or ALT activity was reported. In this study, a history of alcohol abuse was elicited in $38 \%$ of patients, perhaps accounting in part for the frequency of advanced fibrosis. Sterling et al., (1999) evaluated liver histology in 50 consecutive patients with chronic HCV awaiting renal transplantation. Bridging fibrosis or cirrhosis was present in $22 \%$, which was not significantly different from a control group of $\mathrm{HCV}$-positive patients with intact renal function and normal ALT, although there was a trend toward more fibrosis in the dialysis group.

The impact of renal transplantation on the natural history of HCV infection has been shown by Zylberberg et al. In a case-control study including 28 kidney transplanted HCV-infected patients compared with 28 matched immunocompetent controls, they observed histopathological deterioration in $70 \%$ of the transplanted patients compared to $19 \%$ of the controls. The median time elapsed between kidney transplantation and the final liver biopsy in the study was 13.6 years (range 2.6-23.9 years). The progressive nature of liver disease in $\mathrm{HCV}$-infected renal transplanted recipients is probably related to numerous factors. There is evidence that acute $\mathrm{HCV}$ acquired perioperatively acts more aggressively in such patients, perhaps reflecting an acute infection at the time the patient is receiving maximum immunosuppression. It appears that therapeutic immunosuppression following renal transplant may accelerate the course of $\mathrm{HCV}$ infection leading to hepatocellular failure. On the other hand, the overall survival advantage conferred by transplant may outweigh the potential negative effects of immunosuppression for many renal transplant patients.

\section{Impact of viral eradication on mortality related to hepatitis}

Despite the fact that HCV and HBV infections adversely affect the survival of dialysis and renal transplant patients and its high prevalence in these groups of patients, large clinical trials are rare.

\subsection{Hemodialysis patients}

Due to the negative long-term impact of $\mathrm{HCV}$ infection after transplantation and to the current lack of treatment options for $\mathrm{HCV}$ after kidney transplantation, treatment of haemodialysis patients should be attempted when possible.

Careful patient selection and side effect management are important. Combination treatment with pegylated interferon and ribavirin might be considered by experienced physicians, with individualized ribavirin dosing and substantial hematopoietic support, as suggested by few preliminary studies.

The optimal treatment of $\mathrm{HCV}$ in dialysis patients and a more in depth profile of patients has not been determined. We perform Electroencephalography, and echocardiography in order to be aware of unexpected risks and therefore be able to prevent them.

\subsection{Therapeutic options after kidney transplant}

Although treatment of kidney transplants recipients who have hepatitis $C$ is not routinely recommended because of the potential risk for precipitating rejection, some clinical presentations warrant consideration of interferon-based therapy. The most pressing reasons to consider HCV therapy are recurrent and progressive HCV-associated glomerulopathy in the transplanted kidney, severe cholestatic hepatitis, and advanced histologic stages of liver disease. 


\subsection{HCV-mediated glomerulonephritis}

HCV-mediated glomerulonephritis may be effectively managed with interferon-based therapy. The current "best therapy" for these situations is combination therapy with interferon and ribavirin, because combination therapy is the most likely to achieve a sustained viral response.

\section{Algorithms and new perspectives}

Although practices regarding whether patients with cirrhosis should be referred for combined liver and kidney transplantation or whether they should be considered for kidney transplantation alone vary by center, an algorithm for assessment of the fibrosis stage or presence of cirrhosis and evaluation for anti- hepatitis $C$ treatment may be suggested.

By adding non invasive methods such as Fibroscan to the routine tests (abdominal ultrasonography with Doppler and blood analysis) liver biopsy may be avoided in the majority of cases and it could be indicated only when there is a discrepancy between clinical and analytical data.

Patients with liver cirrhosis with portal hypertension, and who had some liver decompensation do not need liver biopsy and have to be considered candidates to combined liver and kidney transplant while patients with cirrhosis or advanced fibrosis should undergo more in depth studies.

\section{Conclusion}

- At present, Hepatitis C and B infection represent a major medical and epidemiologic challenge both in patients on renal replacement therapy and patients undergoing kidney transplantation. The major concern, however, is the lack of safe and effective drugs to treat $\mathrm{HCV}$-infected patients with chronic kidney disease.

- Unfortunately, there have not been any large scale clinical trials performed on this population, therefore the evidence for treatment recommendations is scant and the role of liver biopsy in selected cases is vigent.

- Assessment of the severity of liver fibrosis is important in decision making in patients with chronic hepatitis $C$ under dialysis which is why liver biopsy is still regarded as the reference method to assess the grade of inflammation and the stage of fibrosis. Patients on dialysis, even those diagnosed with chronic hepatitis, have the possibility to receive a kidney transplant, which may have a more favourable evolution if prior to transplant viral eradication is achieved. Another concern in patients also suffering from chronic liver disease is deciding whether they will only need a kidney transplant or whether a combined kidney and liver transplantation is necessary.

- Until recently, a combined transplant was always recommended for patients with advanced fibrosis or cirrhosis. However, nowadays due to a lack of donors, in some centers, patients are only being referred for a kidney transplant, providing that the patient has never suffered from decompensated liver disease.

- Furthermore, in recent years transient elastography (Fibroscan) has been progressively introduced in order to resolve diagnosis uncertainty regarding the fibrosis stage in different clinical settings, especially in patients with chronic hepatitis $C$ due to its high prevalence worldwide, but it has not been validated for kidney patients yet. 
- In kidney transplant recipients, HCV infection is associated with an increased risk of de novo glomerulonephritis and liver-related mortality, both HCV related.

- In conclusion, as cirrhosis is an important predictor of poor post-kidney transplant survival after kidney transplantation, it is advisable to obtain a liver biopsy from selected HCV-positive kidney transplant candidates, considering that the combination of common blood tests, abdominal echography and Fibroscan can improve accuracy and reduce the necessity of using liver biopsy.

\section{References}

Print Book

Kanel, G. C. \& Korula, J. (2011) Atlas of Liver Pathology, (3rd Edition) Elsevier Saunders, ISBN 978-1-4377-0765-6, Philadelphia, PA 19103-2899

Papers in journals

Ahmed, M.S., Wong, C.F., Shawki, H., et al., (2008) Rapidly deteriorating renal function with membranoproliferative glomerulonephritis Type 1 associated with hepatitis $C$ treated successfully with steroids and antiviral therapy: a case report and review of literature. Clin Nephrol. Vol 69, No issue 4, pp. (298-301), ISSN 1555-9041

Alavian, S. M. (2009) A shield against a monster: Hepatitis C in hemodialysis patients. World J Gastroenterol, Vol 15, No issue 6, pp. (641-646), ISSN 1007-9327

Alric, L., Kamar, N. Bonnet, D. et al., (2009) Comparison of liver stiffness, fibrotest and liver biopsy for assessment of liver fibrosis in kidney-transplant patients with chronic viral hepatitis. Transpl Int, Vol 22, No issue 5, pp (568-573), ISSN 0934-0874

Angelico, M. Morosetti, M. Passalacqua, S. et al., (2000) Low levels of hepatitis C virus RNA in blood of infected patients under maintenance haemodialysis with highbiocompatibility, high-permeability filters. Dig Liver Dis, Vol 32, No issue 8, pp. (724-728), ISSN 1590-8658

Aoufi Rabih, S., \& García Agudo, R. (2011) Management of HCV infection in chronic kidney disease. Nefrología. (Official Publication of the Spanish Nephrology Society), Vol 31, No issue 3, pp. (260-267), ISSN 0211-6995

Aroldi, A. Lampertico, P. Montagnino, G. et al., (2005) Natural history of hepatitis B and C in renal allograft recipients. Transplantation, Vol 79, No issue 9, pp. (1132-1136), ISSN 1534-0608.

Bedossa, P., Dargère, D., Paradis, V. (2003) Sampling variability of liver fibrosis in chronic hepatitis C. Hepatology, Vol 38, No issue 6, pp. (1449-1457), ISSN 1665-2681

Bedossa, P., Poynard, T. (1996) An algorithm for the grading of activity in chronic hepatitis C. The METAVIR Cooperative Study Group. Hepatolog, Vol 24, No issue 2, pp. (289293), ISSN 1665-2681

Bejarano, P.A, Koehler, A. \& Sherman, K.E. (2001) Second opinion pathology in liver biopsy interpretation. Am J Gastroenterol, Vol 96, No issue11, pp.(3158-3164), ISSN 00029270

Borroni, G. Ceriani, R., Cazzaniga, M. et al., (2006) Comparison of simple tests for the noninvasive diagnosis of clinically silent cirrhosis in chronic hepatitis C Aliment Pharmacol \& Therap, Vol 24, No issue 5, pp.(797-804), ISSN0269-2813, 1365-2036 
Bravo, A.A., Sheth, S.G., Chopra, S. (2001) Liver biopsy. N Engl J Med, Vol 34, No issue 7, pp. (495-500), ISSN 0028-4793

Carriero, D., Fabrizi, F., Uriel, A.J., et al., (2008) Treatment of dialysis patients with chronic hepatitis C using pegylated interferon and low-dose ribavirin. Int J Artif Organs, Vol 31, No issue 4, pp. (295-302), ISSN 0391-3988

Carrión, J.A., Navasa, M., Bosch, J., et al., (2006) Transient elastography for diagnosis of advanced fibrosis and portal hypertension in patients with $\mathrm{C}$ recurrence after liver transplantation. Liver Transplantation, Vol.12, No.12, pp. (1791-1798),_ISSN1527-6465

Casanovas-Taltavull, T., Baliellas, C., Benasco, C., et al., (2001) Efficacy of interferon for chronic hepatitis $\mathrm{C}$ virus-related hepatitis in kidney transplant candidates on hemodialysis: results after transplantation. Am J Gastroenterol, Vol 96, No issue 4 , pp. (1170-1177), ISSN 0002-9270

Castéra, L., Faucher, J., Bernard, P.H., et al., (2010) Pitfalls of liver stiffness measurement: A 5 -year prospective study of 13,369 examinations. Hepatology, Vol.51, No.3, pp. (828835), ISSN 1665-2681

Cholongitas, E., Quaglia, A., Samonakis, D., et al., (2006) Transjugular liver biopsy: how good is it for accurate histological interpretation?. Gut, Vol 55, No issue 12, pp. (1789-1794),_ISSN 0017-5749

Colloredo, G., Guido, M., Sonzogni, A., Leandro, G. (2003) Impact of liver biopsy size on histological evaluation of chronic viral hepatitis: the smaller the sample, the milder the disease. J Hepatol, Vol 39, No issue 2, pp. (239-244), ISSN 0168-8278

Cruzado, J.M., Casanovas-Taltavull, T., Torras, J., et al., (2003) Pretransplant interferon prevents hepatitis $\mathrm{C}$ virus-associated glomerulonephritis in renal allografts by HCV-RNA clearance. Am J Transplant, Vol 3, No issue 3, pp. (357-360), ISSN 16006143

Daudé, M., Rostaing, L., Sauné, K., et al., (2011) Tenofovir therapy in hepatitis B viruspositive solid-organ transplant recipients. Transplantation, Vol 91, No issue 8, pp. (916-920), ISSN 1534-0608

Delladetsima, J.K., Boletis, J.N., Makris, F., et al., (1999) Fibrosing cholestatic hepatitis in renal transplant recipients with hepatitis C virus infection. Liver Transpl Surg, Vol 5, No issue 4, pp. (294-300), ISSN 1074-3022

Desmet, V. (1997) Histological classification of chronic hepatitis. Acta Gastroenterol Belg, Vol 60, No issue 4, pp. (259-2567), ISSN 0001-5644

Desmet, V. (2003a) Liver tissue examination. J Hepatol, Vol 39, Suppl 1, pp. (S43-S49), ISSN 0168-8278

Desmet, V. (2003b) a "Knodell RG, Ishak KG, et al., Formulation and application of a numerical scoring system for assessing histological activity in asymptomatic chronic active hepatitis. [Hepatology, 1981; Vol 1, pp. 431-435]". Journal of Hepatology, Vol 38, No issue 4, pp. (382-386), ISSN 0168-8278

Espinosa, M., Martn-Malo, A., Ojeda, R., et al., (2004) Marked reduction in the prevalence of hepatitis $\mathrm{C}$ virus infection in hemodialysis patients: causes and consequences. Am J Kidney Dis, Vol 43, No issue 4, pp. (685-689), ISSN 0272-6386 
Fabrizi, F, Martin P, Dixit V, Bunnapradist S (2004) Meta-analysis: Effect of hepatitis C virus infection on mortality in dialysis. Aliment Pharmacol Ther, Vol 20, No issues 11-12, pp. (1271-1277), ISSN 0269-2813, 1365-2036

Fabrizi, F., Takkouche, B., Lunghi, G., et al., (2007) The impact of hepatitis C virus infection on survival in dialysis patients: meta-analysis of observational studies. J Viral Hepat, Vol 14, No issue 10, pp. (697-703), ISSN 1352-0504

Fabrizi, F., Dixit, V., Messa, P., Martin, P. (2008) Interferon monotherapy of chronic hepatitis $\mathrm{C}$ in dialysis patients: meta-analysis of clinical trials. J Viral Hep, Vol 15, No issue 2, pp. (79-88), ISSN 1352-0504

Fabrizi, F., Dixit, V., Messa, P., Martin, P. (2010b) Pegylated interferon monotherapy of chronic hepatitis $\mathrm{C}$ in dialysis patients: Meta-analysis of clinical trials. J Med Virol, Vol 82, No issue 5, pp. (768-775), ISSN 0146-6615

Fabrizi, F., Martin, P. \& Messa, P. (2010a) Hepatitis B and hepatitis C virus and chronic kidney disease. Acta Gastroenterol Belg, Vol 73, No issue 4, pp. (465-471), ISSN 00015644

Fontana, R.J. \& Lok, A.S.F. (2002) Noninvasive Monitoring of Patients With Hepatitis C Hepatology, Vol 36, No issue 5, Suppl 1, pp. (S57-S64), ISSN 1665-2681

Forns, X., Ampurdanès, S., Llove,t J.M., et al., (2002) Identification of chronic hepatitis C patients without hepatic fibrosis by a simple predictive model. Hepatology, Vol 36, No issue 4, Pt 1, pp. (986-992), ISSN 1665-2681

Gaiani, S., Gramantieri, L., Venturoli, N., et al., (1997) What is the criterion for differentiating chronic hepatitis from compensated cirrhosis? A prospective study comparing ultrasonography and percutaneous liver biopsy. J Hepatol, Vol 27, No issue 6, pp. (979-985), ISSN 0168-8278

Gane, E. \& Pilmore, H., (2002) Management of chronic viral hepatitis before and after renal transplantation. Transplantation, Vol 74, No issue 4, pp. (427-437), ISSN 1534-0608

Ghany, M.G., Lok, A.S., Everhart, J.E., et al. (2010) HALT-C Trial Group. Predicting clinical and histologic outcomes based on standard laboratory tests in advanced chronic hepatitis C. Gastroenterology, Vol 138, No issue 1, pp. (136-146), ISSN 0002-9270

Gordon, C.E., Uhlig, K., Lau, J., et al., (2009) Interferon for hepatitis C virus in hemodialysis-an individual patient meta-analysis of factors associated with sustained virological response. Clin J Am Soc Nephrol, Vol 4, No issue 9, pp. (1449-1458), ISSN: 1555-9041

Hanafusa, T., Ichikawa, Y., Kishikawa, H., et al., (1998) Retrospective study on the impact of hepatitis $C$ virus infection on kidney transplant patients over 20 years. Transplantation, Vol 66, No issue 4 , pp. (471-476), ISSN 1534-0608

Hinrichsen, H., Leimenstoll, G., Stegen, G., et al., (2002) PHV Study Group. Prevalence and risk factors of hepatitis $\mathrm{C}$ virus infection in haemodialysis patients: a multicentre study in 2796 patients. Gut, Vol 51, No issue 3, pp. (429-433), ISSN 0017-574

Hirche, T.O., Ignee, A., Hirche, H., et al., (2007) Evaluation of hepatic steatosis by ultrasound in patients with chronic hepatitis C virus infection. Liver Int, Vol 27, No issue 6, pp. (748-757), ISSN 1478-322

Hmaied, F., Ben Mamou, M., Saune-Sandres, K., et al., (2006) Hepatitis C virus infection among dialysis patients in Tunisia: incidence and molecular evidence for 
nosocomial transmission. J Med Viro, Vol 78, No issue 2, pp. (185-191), ISSN 10969071

Huraib, S., al-Rashed, R., Aldrees, A., et al., (1995) High prevalence of and risk factors for hepatitis $C$ in haemodialysis patients in Saudi Arabia: a need for new dialysis strategies. Nephrol Dial Transplant, Vol 10, No issue 4, pp. (470-474),. ISSN 09320509

Huskey J, Wiseman AC. (2011) Chronic viral hepatitis in kidney transplantation. Nat Rev Nephro, Vol 7, No issue 3, pp. (156-165) , ISSN 1759-5061

Jadoul, M., Poignet, J.L., Geddes, C., et al., (2004) HCV Collaborative Group. The changing epidemiology of hepatitis $\mathrm{C}$ virus (HCV) infection in haemodialysis: European multicentre study. Nephrol Dial Transplant, Vol 19 , No issue 4, pp. (904-909), ISSN 0931-0509

Kaiser, T., Damerow, H.C., Tenckhoff, S., et al., (2008) Kinetics of hepatitis C viral RNA and $\mathrm{HCV}$-antigen during dialysis sessions: evidence for differential viral load reduction on dialysis. J Med Virol., Vol 80, No issue 7, pp. (1195-1201), ISSN 0146-6615

Kalambokis, G., Christou, L., Stefanou, D., et al., (2007) Association of liver cirrhosis related IgA nephropathy with portal hypertension. World J Gastroenterol, Vol 13, No issue 43, pp. (5783-5786), ISSN 1007-9327

Kidney Disease: Improving Global Outcomes (KDIGO). (2008) KDIGO clinical practice guidelines for the prevention, diagnosis, evaluation, and treatment of hepatitis $\mathrm{C}$ in chronic kidney disease. Kidney Int, Vol 73, Suppl 109s, pp.( S1-S99), ISSN 0098-6577

Lackner, C., Struber, G., Liegl, B., et al., (2005) Comparison and validation of simple noninvasive tests for prediction of fibrosis in chronic hepatitis C. Hepatology, Vol 41, No issue 6, pp. (1376-1382), ISSN: 1665-2681

Lavanchy, D. (2009) The global burden of hepatitis C. Liver Int, Vol 29, Suppl 1, pp. (74-81), ISSN 1478-3223

Light, J.A., Metz, S., Oddenino, K., et al., (1982) Donor-specific transfusion with diminished sensitization. Transplantation, Vol 34, No issue 6, pp. (352-355), ISSN 1534-0608

Lopes, E.P., Gouveia, E.C., Albuquerque, A.C., et al., (2006) Determination of the cut-off value of serum alanine aminotransferase in patients undergoing hemodialysis, to identify biochemical activity in patients with hepatitis C viremia. J Clin Virol, Vol 35, No issue 3, pp. (298-302), ISSN 1386-6532

Martin, P., Carter, D., Fabrizi, F., et al., (2000) Histopathological features of hepatitis C in renal transplant candidates. Transplantation, Vol 69, no Issue 7, pp. (1479-1484), ISSN 1534-0608

Martin, P. \& Fabrizi, F. (2008) Kidney Disease in Patients with Chronic Hepatitis C. J Hepatol, Vol 49, No issue 4, pp. (613-624), ISSN 0168-8278

Martínez, S.M., Crespo, G., Navasa, M., \& Forns X. (2011) Noninvasive assessment of liver fibrosis. Hepatology, Vol 53, No issue 1, pp. (325-335), ISSN 1665-2681

Mathurin, P., Mouquet, C., Poynard, T. et al., (1999) Impact of hepatitis B and C virus on kidney transplantation outcome. Hepatology, Vol 29, No issue 2, pp. ( 257-263), ISSN 1665-2681 
McLaughlin, K.J., Cameron, S.O., Good, T., et al., (1997) Nosocomial transmission of hepatitis C virus within a British dialysis centre. Nephrol Dial Transplant, Vol 12, No issue 2, pp. (304-309), ISSN 1460-2385

Morales, J.M., Marcén, R., Andres, A., et al. (2010) Renal transplantation in patients with hepatitis $C$ virus antibody. A long national experience. NDT Plus, Vol 3, (Suppl- 2), ii41-ii46, ISSN 1753-0792 ISSN 1753-0784

Noureddin, M. \& Ghany, M.G. (2010) Pharmacokinetics and pharmacodynamics of peginterferon and ribavirin: implications for clinical efficacy in the treatment of chronic hepatitis C. Gastroenterol Clin North Am, Vol 39, No issue 3, pp. (649-658), ISSN 1558-1942

Okoh, E.J., Bucci, J.R., Simon, J.F. \& Harrison, S.A. (2008) HCV in patients with end-stage renal disease. Am J Gastroenterol, Vol 103, No issue 8, pp. (2123-2134), ISSN 00029270

Orloff, S.L., Stempel, C.A., Wright, T.L., et al., (1995) Long-term outcome in kidney transplant patients with hepatitis C (HCV) infection. Clin Transplant, Vol 9, No issue 2, pp. (119-124), ISSN 0902-0063

Persico, M., Palmentieri, B., Vecchione, R., et al., (2002a) Diagnosis of chronic liver disease: reproducibility and validation of liver biopsy. Am J Gastroenterol, Vol 97, No issue 2, pp. (491-492), ISSN 0002-9270

Persico, M., Palmentieri, B., Coppola, L., et al., (2002b) Occurrence of HCC in asymptomatic HCV-related chronic hepatitis. Dig Dis Sci, Vol 47, No issue 11, pp. (2407-2410), ISSN: $1590-8658$

Pouteil-Noble, C., Tardy, J.C., Chossegros, P., et al., (1995) Co-infection by hepatitis B virus and hepatitis $C$ virus in renal transplantation: morbidity and mortality in 1098 patients. Nephrol Dial Transplant, Vol 10, Suppl 6, pp. (122-124), ISSN 0931-0509

Rousselet, M.C., Michalak, S., Dupré, F., et al. (2005) Sources of variability in histological scoring of chronic viral hepatitis. Hepatology, Vol 41, No issue 2, pp. (257-264), ISSN 1665-2681

Salama, G., Rostaing, L., Sandres, K. \& Izopet, J. (2000) Hepatitis C virus infection in French hemodialysis units: a multicenter study. J Med Virol, Vol 61, No issue 1, pp. (44-51), ISSN 1096-9071

Santos, M.A. \& Souto, F.J. (2007) Infection by the hepatitis C virus in chronic renal failure patients undergoing hemodialysis in Mato Grosso state, central Brazil: a cohort study. BMC Public Health, Vol 7, pp. (32-40), ISSN 1471-2478

Scott, D.R., Wong, J.K., Spicer, T.S., et al., (2010) Adverse impact of hepatitis C virus infection on renal replacement therapy and renal transplant patients in Australia and New Zealand.Transplantation, Vol 90, No issue 11, pp. (1165-1171), ISSN 15340608

Sebastiani, G. \& Alberti, A. (2006) Non invasive fibrosis biomarkers reduce but not substitute the need for liver biopsy. World J Gastroenterol, Vol 12, No issue 23, pp. (3682-3694), ISSN 1007-9327

Sebastiani, G., Halfon, P., Castera, L., et al., (2009) SAFE biopsy: a validated method for large-scale staging of liver fibrosis in chronic hepatitis C. Hepatology, Vol 49, No issue 6, pp. (1821-1827), ISSN 1665-2681 
Sebastiani, G., Vario, A., Guido, M., et al., (2006) Stepwise combination algorithms of noninvasive markers to diagnose significant fibrosis in chronic hepatitis C. J Hepatol, Vol 44, No issue 4, pp. (686-693), ISSN 0168-8278

Seeff, L.B., Everson, G.T., Morgan, T.R., et al., (2010) HALT-C Trial Group. Complication rate of percutaneous liver biopsies among persons with advanced chronic liver disease in the HALT-C trial. Clin Gastroenterol Hepatol, Vol 8, No issue 10, pp.(877883), ISSN 1542-3565

Sezer, S., Ozdemir, F.N., Akcay, A., et al., (2004) Renal transplantation offers a better survival in HCV-infected ESRD patients. Clin Transplant, Vol 18, No issue 5, pp. (619-623), ISSN 1399-0012

Shaheen, A.A., Wan, A.F., Myers, R.P. (2007) FibroTest and FibroScan for the prediction of hepatitis C-related fibrosis: a systematic review of diagnostic test accuracy. Am J Gastroenterol , Vol 102, No issue 11, pp. (2589-600), ISSN 0002-9270

Shamshirsaz, A.A., Kamgar, M., Bekheirnia, M. R. et al., (2004) The role of hemodialysis machines dedication in reducing Hepatitis $C$ transmission in the dialysis setting in Iran: A multicenter prospective interventional study. BMC Nephrol, Vol 5, Oct 7, pp. (13-17), ISSN 1471-2369

Siddique, I., El-Naga, H.A., Madda, J.P., et al., (2003) Sampling variability on percutaneous liver biopsy in patients with chronic hepatitis $\mathrm{C}$ virus infection. Scand $J$ Gastroenterol, Vol 38, No issue 4, pp. (427-432), ISSN 0036-5521

Standish, R.A., Cholongitas, E., Dhillon, A., et al., (2006) An appraisal of the histopathological assessment of liver fibrosis. Gut, Vol.55, No 4, pp. (569-578), ISSN 0017-5749

Stasi, C., Arena, U., Vizzutti, F., et al., (2009) Transient elastography for the assessment of liver fibrosis in patients with chronic viral hepatitis: the missing tool?. Dig Liver Dis, Vol 41, No issue 12, pp. (863-866), ISSN 1590-8658

Sterling, R.K., Sanyal, A.J., Luketic, V.A., et al., (1999) Chronic hepatitis C infection in patients with end stage renal disease: characterization of liver histology and viral load in patients awaiting renal transplantation. Am J Gastroenterol, Vol 94, No issue 12, pp. (3576-3582), ISSN: 0002-9270

Tannapfel, A. \& Wittekind, C. (2001) Preneoplasia of the liver. Definition-differential diagnosis-clinical consequences. Pathologe, Vol 22, No issue 6, pp. (399-406), ISSN 0172-8113

Tobkes, A.I. \& Nord, H.J. (1995) Liver biopsy: review of methodology and complications. Dig Dis. Sci, Vol13, No issue 5, pp: (267-74), ISSN 1573-2568

Vallet-Pichard, A., Fontaine, H., Mallet, V. \& Pol, S. (2011a) Viral hepatitis in solid organ transplantation other than liver. J Hepatol, Vol 55, No issue 2, pp (472-478) PMID: 21241754. ISSN 0168-8278

Vallet-Pichard, A., Pol, S., Mallet, V., (2011b) Assessment and reversibility of liver fibrosis in viral hepatitis. Rev Prat.,Vol 61 No issue 1 pp. (39-43), ISSN:0035-2640

Viganò, M., Colombo, M., Aroldi, A., et al., (2005) Long-term lamivudine monotherapy in renal-transplant recipients with hepatitis-B-related cirrhosis. Antivir Ther Vol10 No issue 6 pp. (709-713), ISSN 1359-6535 
Vizzutti, F., Arena, U., Marra, F. \& Pinzani, M, (2009) Elastography for the non-invasive assessment of liver disease: limitations and future developments. Gut, Vol.58, No.2, pp. (157-160), ISSN 0017-5749

Zeman, M., Campbell, P. \& Bain, V.G. (2006) Hepatitis C eradication and improvement of cryoglobulinemia-associated rash and membranoproliferative glomerulonephritis with interferon and ribavirin after kidney transplantation. Can J Gastroenterol, Vol 20 No issue 6 pp. (427-431), ISSN 0835-7900

Ziol, M., Handra-Luca, A., Kettaneh, A., et al., (2005) Noninvasive asessment of liver fibrosis by measurement of stiffnss in patients with chronic hepatitis C. Hepatology, Vol.41, No. 1, pp: (48-54), ISSN 1665-2681

Zylberberg, H., Nalpas, B., Carnot, F., et al., (2002) Severe evolution of chronic hepatitis C in renal transplantation: a case control study. Nephrol Dial Transplant, Vol 17, No issue 1 , pp. (129-133, ISSN 0931-0509) 


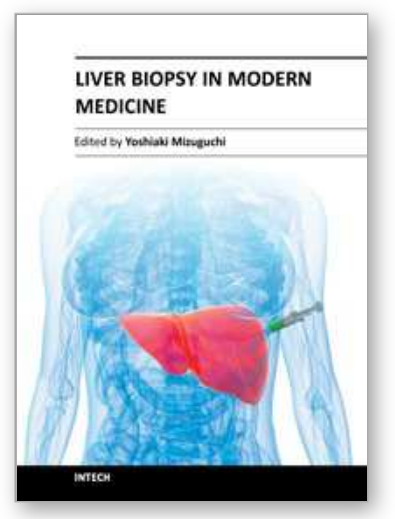

\author{
Liver Biopsy in Modern Medicine \\ Edited by Dr. Yoshiaki Mizuguchi
}

ISBN 978-953-307-883-0

Hard cover, 378 pages

Publisher InTech

Published online 10, October, 2011

Published in print edition October, 2011

Liver biopsy, first performed by Paul Ehrlich in 1883, remains an important diagnostic procedure for the management of hepatobiliary disorders and the candidate/donated organ for transplantation. The book "Liver biopsy in Modern Medicine" comprises 21 chapters covering the various aspects of the biopsy procedure in detail and provides an up-to-date insightful coverage to the recent advances in the management of the various disorders with liver biospy. This book will keep up with cutting edge understanding of liver biopsy to many clinicians, physicians, scientists, pharmaceutics, engineers and other experts in a wide variety of different disciplines.

\title{
How to reference
}

In order to correctly reference this scholarly work, feel free to copy and paste the following:

Teresa Casanovas, Carme Baliellas and Maria Carmen Peña Cala (2011). The Present Role of Liver Biopsy in Kidney Transplant Candidates in the Management of Hepatitis B and C Patients, Liver Biopsy in Modern Medicine, Dr. Yoshiaki Mizuguchi (Ed.), ISBN: 978-953-307-883-0, InTech, Available from: http://www.intechopen.com/books/liver-biopsy-in-modern-medicine/the-present-role-of-liver-biopsy-in-kidneytransplant-candidates-in-the-management-of-hepatitis-b-an

\section{INTECH}

open science | open minds

\section{InTech Europe}

University Campus STeP Ri

Slavka Krautzeka 83/A

51000 Rijeka, Croatia

Phone: +385 (51) 770447

Fax: +385 (51) 686166

www.intechopen.com

\section{InTech China}

Unit 405, Office Block, Hotel Equatorial Shanghai

No.65, Yan An Road (West), Shanghai, 200040, China

中国上海市延安西路65号上海国际贵都大饭店办公楼 405 单元

Phone: +86-21-62489820

Fax: +86-21-62489821 
(C) 2011 The Author(s). Licensee IntechOpen. This is an open access article distributed under the terms of the Creative Commons Attribution 3.0 License, which permits unrestricted use, distribution, and reproduction in any medium, provided the original work is properly cited. 